Artigo / Article

\title{
Leucemia Mielóide Crônica - Causas de falha do tratamento com mesilato de imatinibe
}

\author{
Chronic Myeloid Leukemia - Causes of treatment failure with imatinib
}

Katia B. B. Pagnano

\section{Introdução}

O mesilato de imatinibe (MI) é atualmente o tratamento de primeira linha da LMC e sua ação decorre da sua capacidade de inibição da tirosino quinase BCR-ABL através da ligação competitiva com o sítio de ligação com ATP. Em pacientes recém-diagnosticados em fase crônica, o tratamento com MI em primeira linha resulta numa alta taxa de resposta hematológica ( $98 \%$ ), de resposta citogenética completa (RCC) de $87 \%$ e de sobrevida global de $89 \%$ em 60 meses. ${ }^{1}$ A taxa de progressão anual é cerca de $4 \%$ no total, incluindo perda de resposta hematológica e citogenética, sendo que $2 \%$ dos pacientes evoluem para Fase Acelerada (FA) ou Crise Blástica (CB). As taxas de progressão caem com o tempo, mas, de um modo geral, podemos dizer que, apesar dos excelentes resultados, cerca de $15 \%$ vão apresentar alguma forma de resistência ao tratamento. ${ }^{1}$ Os casos com início tardio de MI e com doença mais avançada terão uma maior taxa de resistência. Pacientes tratados com MI em FA e CB terão perda da resposta em $51 \%$ e $88 \%$ respectivamente em dois anos. ${ }^{2}$

\section{Falhas de Tratamento - Causas}

Os critérios para definição de falha de tratamento e resposta subótima foram recentemente publicados pelo grupo de especialistas do LeukemiaNet, baseado no resultados do estudo IRIS. ${ }^{3}$ Muitos dos conceitos provavelmente sofrerão alterações, em face dos resultados obtidos com os novos inibidores. Os critérios atuais definem como falha de tratamento a ausência de alguma resposta hematológica aos três meses, ausência de resposta hematológica completa ou qualquer resposta citogenética aos seis meses, ausência de resposta citogenética maior aos 12 meses e RCC aos 18 meses, além de perda da RH e RCC e mutações com alto grau de insensibilidade ao MI. Nesses casos, deve ser feita alguma intervenção terapêutica, como aumento de dose, mudança para outro inibidor ou encaminhamento para transplante de medula óssea. Resposta subótima foi definida como falha em atingir resposta hematológica completa aos três meses de tratamento, ausência de resposta citogenética parcial aos seis meses e ausência de RCC aos 12 meses, ausência de respos-

Médica Assistente da Disciplina de Hematologia e do Centro de Hematologia e Hemoterapia da Faculdade de Ciências Médicas da Universidade Estadual de Campinas-SP

Correspondência: Katia Borgia Barbosa Pagnano

Hemocentro - Unicamp

Rua Carlos Chagas, 480

113083-970 - Campinas-SP - Brasil

E-mail:kborgia@unicamp.br 
ta molecular maior aos 18 meses, evolução clonal, perda da resposta molecular maior e mutações com baixo grau de insensibilidade ao imatinibe. ${ }^{3}$ No caso de resposta subótima, o paciente provavelmente não se beneficiaria com MI em longo prazo e poderia ser tentado aumento de dose ou tratamento com outro inibidor.

A resistência pode ser considerada primária se o paciente nunca apresentou resposta ao tratamento e secundária quando ocorre perda da resposta adquirida. ${ }^{4}$ Pode ser classificada como hematológica, citogenética e molecular. ${ }^{2}$ A resistência hematológica primária e secundária é rara em pacientes em fase crônica precoce e ocorre em $2 \%-4 \%$ dos pacientes. Já a resistência citogenética primária pode ocorrer em $15 \%-25 \%$ e está relacionada à capacidade de inibição do BCR$\mathrm{ABL}$ e à reserva de precursores normais na medula óssea. $\mathrm{A}$ reserva de precursores normais pode ser afetada, por exemplo, por tratamentos anteriores (agentes alquilantes, interferon). A resistência primária e secundária é mais freqüente nas fases avançadas. ${ }^{5-7}$

A resistência ao imatinibe pode ser multifatorial e os principais mecanismos foram revisados numa recente publicação ${ }^{8}$ e serão comentados a seguir.

Como todo medicamento oral, problemas na ingestão do imatinibe (má aderência ao tratamento), absorção, metabolização, ligação com proteínas plasmáticas, influxo e efluxo do MI para dentro da célula e inativação enzimática podem também interferir na ação terapêutica, levando a uma diminuição dos níveis plasmáticos da droga. Picard et al ${ }^{9}$ demonstraram correlação entre níveis plasmáticos baixos de MI e falha em alcançar resposta citogenética. Uma subanálise do estudo IRIS também mostrou que os pacientes cujas concentrações plasmáticas de MI foram maiores que $1000 \mathrm{ng} / \mathrm{mL}$ obtiveram melhores taxas de RCC, resposta molecular maior e sobrevida livre de evento. ${ }^{10} \mathrm{~A}$ concentração plasmática do MI depende da metabolização da droga pelo sistema do citocromo P450 (CYP3A4 e CYP3A5) e pode ser aumentada ou diminuída por alguns medicamentos. Por exemplo, dexametasona, carbamazepina, fenobarbital, fenitoína são indutores do sistema P450 e diminuem o nível plasmático de imatinibe. Já outras drogas como eritromicina, cetoconazol, azitromicina, amiodarona, fluoxetina, são inibidores e, portanto, aumentam o nível plasmático de imatinibe. ${ }^{11}$ A avaliação dos níveis séricos é uma ferramenta interessante e poderia auxiliar nos casos com toxicidade além da esperada com doses convencionais de imatinibe, nos pacientes com falha de resposta ou resposta subótima, na suspeita de não aderência ao tratamento e nos casos onde se suspeita de interação medicamentosa.

A entrada do MI no interior das células é mediada por uma proteína denominada human organic cation transporter 1 (hOCT1), cujos níveis variam de paciente para paciente. ${ }^{12} \mathrm{~A}$ atividade de influxo da OCT-1 e a capacidade de retenção do MI têm impacto nos níveis séricos e na resposta terapêutica. ${ }^{13}$ Entre os pacientes que apresentam alta atividade dessa bomba, $85 \%$ atingem resposta molecular maior aos 24 meses de MI, enquanto nos pacientes com baixa atividade, essa resposta é de $45 \%$. Os pacientes com baixa atividade são os que mais se beneficiam com altas doses de MI. Outra evidência são os resultados com altas doses de MI, que levam a uma maior taxa de resposta citogenética. ${ }^{14}$

As causas de resistência secundária são mais conhecidas. A causa mais freqüente é a perda de inibição do BCR$\mathrm{ABL}$, resultante da presença de mutações do $\mathrm{ABL}$, presente em 50\%-90\% dos casos resistentes, dependendo da sensibilidade do método de detecção utilizado. ${ }^{15-18}$ As mutações podem ocorrer em diversos domínios da quinase, como na alça do fosfato (P-loop), alça de ativação e domínio catalítico. O MI se liga e estabiliza uma conformação inativa da quinase na qual a alça de ativação encontra-se em uma posição fechada. ${ }^{19,20}$ Mutações que ocorrem em sítios de contato com MI eliminam pontes de hidrogênio críticas para a ligação. Outras que ocorrem na alça de fosfato impedem que a quinase assuma uma conformação adequada para a ligação do MI e, por fim, aquelas da alça de ativação estabilizam uma forma ativa, inacessível para o imatinibe. As mutações são mais freqüentes na resistência secundária do que primária $(57 \%$ vs $30 \%$ ) e também nas fases avançadas ( $80 \%$ na fase blástica vs $14 \%$ na fase crônica). ${ }^{18}$ Desde o primeiro relato de mutações em pacientes resistentes em $2001^{15}$ já foram descritas mais de 70 mutações em mais de 50 aminoácidos e muitas delas com importância prognóstica, como as mutações encontradas na alça $\mathrm{P}$ e no aminoácido $315 .{ }^{21-23} \mathrm{Um}$ estudo não observou correlação com pior prognóstico, ${ }^{24}$ mas havia diferenças na casuística e na freqüência de determinadas mutações, além de tratamentos com outros inibidores de TK após o aparecimento da resistência. Em termos das técnicas disponíveis, o seqüenciamento direto é o método mais freqüentemente utilizado na detecção de mutações e tem uma sensibilidade de cerca de $10 \%-20 \% \cdot{ }^{2,25}$ A cromatografia líquida de alta performance (D-HPLC) tem sido usada para triagem de mutações e mostrou ser um método mais sensível que o seqüenciamento, com $1 \%-5 \%$ de sensibilidade. ${ }^{26,27}$ Com essa técnica, foi relatado que, em pacientes em tratamento com imatinibe, a detecção de mutações é altamente preditiva de recaída hematológica, que ocorre geralmente numa mediana de 12,9 meses. As mutações da alça P e a mutação T315I foram detectadas 2,8 e 6,3 meses antes da recaída hematológica, respectivamente. ${ }^{27}$ Outras técnicas mais sensíveis podem detectar mutações pré-tratamento com imatinibe, mas não foi demonstrado que a presença desses clones mutantes em baixos níveis tenham significado prognóstico. ${ }^{28,29}$ No entanto, Khorashad et al, $2006^{30}$ observaram que nem sempre a presença de uma mutação pode explicar a resistência. Há casos onde há discordância entre a presença de determinada mutação e os níveis de transcritos BCR-ABL. Alguns pacientes mostraram altos índices de clones mutantes e boa resposta ao tratamento, com níveis baixos de transcritos BCR-ABL. Por outro lado, houve casos com níveis altos de BCR-ABL e 
com baixa porcentagem do clone mutante, levando a crer que outros mecanismos estão envolvidos. Mutações foram identificadas em células CD34 de pacientes com RCC e podem contribuir na persistência de clones malignos, levando a recaída. ${ }^{31}$

Quando confirmada falha de tratamento, a análise de mutações pode identificar as relacionadas à resistência que podem auxiliar no planejamento do tratamento, dependendo da sensibilidade ao determinado inibidor de TK, que pode ser avaliado através da concentração inibitória (IC 50), um índice que avalia o quanto a droga é capaz de inibir a linhagem mutante. Quanto maior o IC 50, mais medicamento é necessário para inibir a TK e, portanto, mais resistente é a mutação. Mutações com baixo grau de insensibilidade ao MI (M244V, M351T e F359V) podem responder ao aumento de dose. Mutações com alto grau de insensibilidade (Y253F, E255K/V) necessitam mudança no tratamento. A mutação T315I é resistente ao MI e aos outros inibidores de segunda e terceira geração, é freqüentemente identificada em pacientes não responsivos ou com perda de resposta aos novos inibidores, devido à seleção de clones resistentes. ${ }^{32-35}$ Esses pacientes seriam candidatos a indicação mais precoce de transplante de medula ou em estudos clínicos de novas drogas sensíveis a essa mutação. A mutação T317L tem sido detectada na resistência ao dasatinibe, porém é sensível ao nilotinibe..$^{36}$ Além da resistência, mutações podem afetar o potencial de transformação do BCR-ABL. Algumas mutações estão envolvidas com ganho ou perda de função da proteína BCR-ABL e levar a um pior prognóstico. ${ }^{37}$

A pesquisa de mutações deve ser realizada nos casos com resposta subótima, com falha de tratamento e aumento dos transcritos BCR-ABL, conforme recomendações da LeukemiaNet. ${ }^{3,25} \mathrm{O}$ quanto deve ser considerado esse aumento ainda é motivo de controvérsia. $O$ grupo australiano encontrou correlação entre a presença de mutações e o aumento de mais de duas vezes no número dos transcritos. ${ }^{38}$ No entanto, esses níveis não foram reproduzíveis em outros laboratórios e. de um modo geral, a maioria dos estudos considera o gatilho para a pesquisa de mutações um aumento entre 0,5 a $1 \log$ (5-10 vezes) nos transcritos, nos casos que nunca atingiram uma resposta molecular maior e aqueles com níveis crescentes de transcritos. ${ }^{39-41}$

Outros mecanismos conhecidos de resistência secundária incluem a superprodução de BCR-ABL decorrente de amplificação gênica, ${ }^{15}$ aparecimento de cromossomos Filadélfia adicionais ou outras anormalidades cromossômicas além do cromossomo $\mathrm{Ph} 1$ (evolução clonal). ${ }^{42,43}$ A evolução clonal está associada a um risco maior de transformação para fases avançadas. Já alterações clonais nas células Ph negativas não têm impacto negativo, e o tratamento não deve ser modificado se não houver evidência de mielodisplasia. ${ }^{44}$ Há também evidências de persistência do BCR-ABL em células precursoras quiescentes que seriam resistentes ao MI. ${ }^{45,46} \mathrm{O}$ aumento de expressão da MDR1 foi observado em linhagens celulares resistentes a MI e foi parcialmente revertido com verapamil, um inibidor da glicoproteína P. Outros estudos avaliaram o papel da glicoproteína $\mathrm{P}$ e mostraram que a expressão da MDR1 confere resistência ${ }^{47,48}$ enquanto outros autores não encontraram relação. ${ }^{49}$ Há outros mecanismos independentes do BCR-ABL, como expressão da LYN quinase, da família da SRC. 50,51

Em resumo, são diversos os mecanismos a serem considerados na falha de tratamento com imatinibe e deve-se, se possível, tentar esclarecê-los no intuito de oferecer ao paciente o melhor tratamento de segunda linha, seja este otimização de dose, outro inibidor de TK ou transplante de medula óssea.

\section{Recomendações}

- Monitorar adequadamente o tratamento da LMC com inibidor de TK através de hemograma, citogenética e PCRquantitativo; caracterizar a falha de tratamento ou resposta subótima de acordo com as recomendações feitas pelo Leukemia Net

- Antes de considerar um paciente resistente é importante checar a aderência ao tratamento, além de interações com outras drogas. A avaliação dos níveis séricos ainda não é disponível na prática clínica, mas no futuro poderá contribuir na verificação de adesão ao tratamento, avaliação de toxicidade e falha de resposta

- Os mecanismos de resistência ainda não estão totalmente elucidados e muitas vezes são multifatoriais, tornando complexo o manejo clínico. Mecanismos de resistência que atualmente são passíveis de investigação na prática clínica incluem evolução clonal e mutações do ABL. Esses resultados podem auxiliar na escolha do melhor tratamento.

\begin{abstract}
Imatinib is currently the treatment of choice of CML, but despite of the excellent results, it is not able to completely eradicate the disease and resistance may occur. The most studied mechanism is the presence of $A B L$ kinase mutations that interfere with imatinib binding and action, gene amplification and clonal evolution. However, there are other mechanisms involved and less studied such as drug absorption and influx and efflux of imatinib. Besides the true causes of resistance, compliance is always a concern and also drug interaction should be checked. An understanding of these mechanisms will certainly contribute to develop new strategies for the treatment of resistant cases. Rev. bras. hematol. hemoter. 2008; 30(Supl.1):22-26.
\end{abstract}

Key words: Chronic myeloid leukemia; imatinib; resistance; treatment failure. 


\section{Referências Bibliográficas}

1. Druker BJ, Guilhot F, OBrien SG, Gathmann I, Kantarjian H, Gattermann $\mathrm{N}$, et al. Five-year follow-up of patients receiving imatinib for chronic myeloid leukemia. N Engl J Med. 2006;355 (23):2408-17.

2. Hochhaus A, Hughes T. Clinical resistance to imatinib: mechanisms and implications. Hematol Oncol Clin North Am. 2004;18:641-56.

3. Baccarani M, Saglio G, Goldman J, Hochhaus A, Simonsson B, Appelbaum F, et al. Evolving concepts in the management of chronic myeloid leukemia: recommendations from an expert panel on behalf of the European LeukemiaNet. Blood. 2006;108(6): 1809-20.

4. Shah NP. Loss of response to imatinib: mechanisms and management. Hematology Am Soc Hematol Educ Program. 2005:183-7.

5. Druker BJ, Sawyers CL, Capdeville R, Ford JM, Baccarani M, Goldman JM. Chronic myelogenous leukemia. Hematology Am Soc Hematol Educ Program. 2001:87-112.

6. Kantarjian H, Sawyers C, Hochhaus A, Guilhot F, Schiffer C, Gambacorti-Passerini C, et al. Hematologic and cytogenetic responses to imatinib mesylate in chronic myelogenous leukemia. N Engl J Med. 2002;346(9):645-52.

7. Ottmann OG, Druker BJ, Sawyers CL, Goldman JM, Reiffers J, Silver RT, et al. A phase 2 study of imatinib in patients with relapsed or refractory Philadelphia chromosome-positive acute lymphoid leukemias. Blood. 2002;100(6):1965-71.

8. Apperley JF. Part I: mechanisms of resistance to imatinib in chronic myeloid leukaemia. Lancet Oncol. 2007;8(11):1018-29.

9. Picard S, Titier K, Etienne G, Teilhet E, Ducint D, Bernard MA, et al. Trough imatinib plasma levels are associated with both cytogenetic and molecular responses to standard-dose imatinib in chronic myeloid leukemia. Blood. 2007;109(8):3496-9.

10. Larson R, Druker BJ, Guilhot F, OBrien S, Riviere GJ, et al. Imatinib pharmacokinetics and its correlation with response and safety in chronic phase chronic myeloid leukemia: a subanalysis of IRIS study. Blood. 2008;DOI 10.1182/blood-2007-10-116475.

11. Marin D, Marktel S, Bua M, Armstrong L, Goldman JM, Apperley $\mathrm{JF}$, et al. The use of imatinib (STI571) in chronic myelod leukemia: some practical considerations. Haematologica. 2002; 87(9):979-88.

12. Thomas J, Wang L, Clark RE, Pirmohamed M. Active transport of imatinib into and out of cells: implications for drug resistance. Blood. 2004;104(12):3739-45.

13. White DL, Saunders VA, Dang P, Engler J, Venables A, Zrim S, et al. Most CML patients who have a suboptimal response to imatinib have low OCT-1 activity: higher doses of imatinib may overcome the negative impact of low OCT-1 activity. Blood. 2007; 110 (12):4064-72.

14. Kantarjian H, Talpaz M, OBrien S, Garcia-Manero G, Verstovsek $\mathrm{S}$, Giles F, et al. High-dose imatinib mesylate therapy in newly diagnosed Philadelphia chromosome-positive chronic phase chronic myeloid leukemia. Blood. 2004;103(8):2873-8.

15. Gorre ME, Mohammed M, Ellwood K, Hsu N, Paquette R, Rao PN, et al. Clinical resistance to STI-571 cancer therapy caused by BCR-ABL gene mutation or amplification. Science. 2001;293 (5531):876-80.

16. Shah NP, Nicoll JM, Nagar B, Gorre ME, Paquette RL, Kuriyan J, et al. Multiple BCR-ABL kinase domain mutations confer polyclonal resistance to the tyrosine kinase inhibitor imatinib (STI571) in chronic phase and blast crisis chronic myeloid leukemia. Cancer Cell. 2002;2(2):117-25.
17. Branford S, Rudzki Z, Walsh S, Grigg A, Arthur C, Taylor K, et al. High frequency of point mutations clustered within the adenosine triphosphate-binding region of $\mathrm{BCR} / \mathrm{ABL}$ in patients with chronic myeloid leukemia or Ph-positive acute lymphoblastic leukemia who develop imatinib (STI571) resistance. Blood. 2002;99(9): 3472-5.

18. Soverini S, Colarossi S, Gnani A, Rosti G, Castagnetti F, Poerio A, et al. Contribution of ABL kinase domain mutations to imatinib resistance in different subsets of Philadelphia-positive patients: by the Gimema Working Party on Chronic Myeloid Leukemia. Clin Cancer Res. 2006;12(24):7374-9.

19. Schindler T, Bornmann W, Pellicena P, Miller WT, Clarkson B, Kuriyan J. Structural mechanism for STI-571 inhibition of abelson tyrosine kinase. Science. 2000;289(5486):1938-42.

20. Nagar B, Bornmann WG, Pellicena P, Schindler T, Veach DR, Miller WT, et al. Crystal structures of the kinase domain of c-Abl in complex with the small molecule inhibitors PD173955 and imatinib (STI-571). Cancer Res. 2002;62(15):4236-43.

21. Branford S, Rudzki Z, Walsh S, Parkinson I, Grigg A, Szer J, et al. Detection of BCR-ABL mutations in patients with CML treated with imatinib is virtually always accompanied by clinical resistance, and mutations in the ATP phosphate-binding loop (P-loop) are associated with a poor prognosis. Blood. 2003; 102 (1):276-83.

22. Soverini S, Martinelli G, Rosti G, Bassi S, Amabile M, Poerio A, et al. ABL mutations in late chronic phase chronic myeloid leukemia patients with up-front cytogenetic resistance to imatinib are associated with a greater likelihood of progression to blast crisis and shorter survival: a study by the Gimema Working Party on Chronic Myeloid Leukemia. J Clin Oncol. 2005;23(18):4100-9.

23. Nicolini FE, Corm S, Le QH, Sorel N, Hayette S, Bories D, et al. Mutation status and clinical outcome of 89 imatinib mesylateresistant chronic myelogenous leukemia patients: a retrospective analysis from the French intergroup of CML (Fi(phi)-LMC Group). Leukemia. 2006;20(6):1061-6.

24. Jabbour E, Kantarjian H, Jones D, Talpaz M, Bekele N, OBrien S, et al. Frequency and clinical significance of BCR-ABL mutations in patients with chronic myeloid leukemia treated with imatinib mesylate. Leukemia. 2006;20(10):1767-73.

25. Hughes T, Deininger M, Hochhaus A, Branford S, Radich J, Kaeda $\mathrm{J}$, et al. Monitoring CML patients responding to treatment with tyrosine kinase inhibitors: review and recommendations for harmonizing current methodology for detecting BCR-ABL transcripts and kinase domain mutations and for expressing results. Blood. 2006;108(1):28-37.

26. Soverini S, Martinelli G, Amabile M, Poerio A, Bianchini M, Rosti G, et al. Denaturing-HPLC-based assay for detection of ABL mutations in chronic myeloid leukemia patients resistant to imatinib. Clin Chem. 2004;50(7):1205-13.

27. Ernst T, Erben P, Muller MC, Paschka P, Schenk T, Hoffmann J, et al. Dynamics of BCR-ABL mutated clones prior to hematologic or cytogenetic resistance to imatinib. Haematologica. 2008; 93(2):186-92.

28. Roche-Lestienne C, Soenen-Cornu V, Grardel-Duflos N, Lai JL, Philippe N, Facon T, et al. Several types of mutations of the Abl gene can be found in chronic myeloid leukemia patients resistant to STI571, and they can pre-exist to the onset of treatment. Blood. 2002;100(3):1014-8.

29. Willis SG, Lange T, Demehri S, Otto S, Crossman L, Niederwieser $\mathrm{D}$, et al. High-sensitivity detection of BCR-ABL kinase domain mutations in imatinib-naive patients: correlation with clonal cytogenetic evolution but not response to therapy. Blood. 2005; 106(6):2128-37.

30. Khorashad JS, Anand M, Marin D, Saunders S, Al-Jabary T, Iqbal $\mathrm{A}$, et al. The presence of a BCR-ABL mutant allele in CML does 
not always explain clinical resistance to imatinib. Leukemia. 2006; 20(4):658-63

31. Chu S, Xu H, Shah NP, Snyder DS, Forman SJ, Sawyers CL, et al. Detection of BCR-ABL kinase mutations in CD34+ cells from chronic myelogenous leukemia patients in complete cytogenetic remission on imatinib mesylate treatment. Blood. 2005; 105(5): 2093-8.

32. Soverini S, Colarossi S, Gnani A, Castagnetti F, Rosti G, Bosi C, et al. Resistance to dasatinib in Philadelphia-positive leukemia patients and the presence or the selection of mutations at residues 315 and 317 in the BCR-ABL kinase domain. Haematologica. 2007;92(3):401-4.

33. Khorashad JS, Milojkovic D, Mehta P, Anand M, Ghorashian S, Reid AG, et al. In vivo kinetics of kinase domain mutations in CML patients treated with dasatinib after failing imatinib. Blood. 2008; 15:111(4):2378-81. Epub Nov. 2007.

34. Shah NP, Skaggs BJ, Branford S, Hughes TP, Nicoll JM, Paquette $\mathrm{RL}$, et al. Sequential ABL kinase inhibitor therapy selects for compound drug-resistant BCR-ABL mutations with altered oncogenic potency. J Clin Invest. 2007;117(9):2562-9.

35. Kantarjian HM, Giles F, Gattermann N, Bhalla K, Alimena G, Palandri F, et al. Nilotinib (formerly AMN107), a highly selective BCR-ABL tyrosine kinase inhibitor, is effective in patients with Philadelphia chromosome-positive chronic myelogenous leukemia in chronic phase following imatinib resistance and intolerance. Blood. 2007;110(10):3540-6.

36. OHare T, Eide CA, Deininger MW. Bcr-Abl kinase domain mutations, drug resistance, and the road to a cure for chronic myeloid leukemia. Blood. 2007;110(7):2242-9.

37. Griswold IJ, MacPartlin M, Bumm T, Goss VL, OHare T, Lee KA, et al. Kinase domain mutants of Bcr-Abl exhibit altered transformation potency, kinase activity, and substrate utilization, irrespective of sensitivity to imatinib. Mol Cell Biol. 2006;6 (16):6082-93

38. Branford S, Rudzki Z, Parkinson I, Grigg A, Taylor K, Seymour JF, et al. Real-time quantitative PCR analysis can be used as a primary screen to identify patients with CML treated with imatinib who have BCR-ABL kinase domain mutations. Blood. 2004;104(9): 2926-32.

39. Wang L, Knight K, Lucas C, Clark RE. The role of serial BCR$\mathrm{ABL}$ transcript monitoring in predicting the emergence of BCRABL kinase mutations in imatinib-treated patients with chronic myeloid leukemia. Haematologica. 2006;91(2):235-9.

40. Cortes J, Talpaz M, O’Brien S, Jones D, Luthra R, Shan J, et al. Molecular responses in patients with chronic myelogenous leukemia in chronic phase treated with imatinib mesylate. Clin Cancer Res. 2005;11(9):3425-32.

41. Press RD, Love Z, Tronnes AA, Yang R, Tran T, MongoueTchokote S, et al. BCR-ABL mRNA levels at and after the time of a complete cytogenetic response (CCR) predict the duration of CCR in imatinib mesylate-treated patients with CML. Blood. 2006; 107(11):4250-6.

42. Hochhaus A, Kreil S, Corbin AS, La Rosee P, Muller MC, Lahaye T, et al. Molecular and chromosomal mechanisms of resistance to imatinib (STI571) therapy. Leukemia. 2002;16(11):2190-6.

43. Marktel S, Marin D, Foot N, Szydlo R, Bua M, Karadimitris A, et al. Chronic myeloid leukemia in chronic phase responding to imatinib: the occurrence of additional cytogenetic abnormalities predicts disease progression. Haematologica. 2003;88(3):260-7.

44. Deininger MW, Cortes J, Paquette R, Park B, Hochhaus A, Baccarani $\mathrm{M}$, et al. The prognosis for patients with chronic myeloid leukemia who have clonal cytogenetic abnormalities in philadelphia chromosome-negative cells. Cancer. 2007;110(7):1509-19.
45. Graham SM, Jorgensen HG, Allan E, Pearson C, Alcorn MJ, Richmond L, et al. Primitive, quiescent, Philadelphia-positive stem cells from patients with chronic myeloid leukemia are insensitive to STI571 in vitro. Blood. 2002;99(1):319-25.

46. Bhatia R, Holtz M, Niu N, Gray R, Snyder DS, Sawyers CL, et al. Persistence of malignant hematopoietic progenitors in chronic myelogenous leukemia patients in complete cytogenetic remission following imatinib mesylate treatment. Blood. 2003; 101 (12): 4701-7.

47. Mahon FX, Belloc F, Lagarde V, Chollet C, Moreau-Gaudry F, Reiffers J, et al. MDR1 gene overexpression confers resistance to imatinib mesylate in leukemia cell line models. Blood. 2003; 101(6):2368-73.

48. Widmer N, Colombo S, Buclin T, Decosterd LA. Functional consequence of MDR1 expression on imatinib intracellular concentrations. Blood. 2003;102(3):1142.

49. Ferrao PT, Frost MJ, Siah SP, Ashman LK. Overexpression of Pglycoprotein in K562 cells does not confer resistance to the growth inhibitory effects of imatinib (STI571) in vitro. Blood. 2003; 102 (13):4499-503.

50. Donato NJ, Wu JY, Stapley J, Gallick G, Lin H, Arlinghaus R, et al. BCR-ABL independence and LYN kinase overexpression in chronic myelogenous leukemia cells selected for resistance to STI571. Blood. 2003;101(2):690-8.

51. Dai Y, Rahmani M, Corey SJ, Dent P, Grant S. A Bcr/Ablindependent, Lyn-dependent form of imatinib mesylate (STI-571) resistance is associated with altered expression of Bcl-2. J Biol Chem. 2004;279(33):34227-39.

O tema apresentado e o convite ao autor constam da pauta elaborada pelos co-editores, Professor Ricardo Pasquini e Professor Cármino Antonio de Souza.

Avaliação: Co-editores e um revisor externo. Publicado após revisão e concordância do editor. Conflito de interesse: não declarado.

Recebido: 12/02/2008

Aceito: $21 / 02 / 2008$ 